\title{
Isolation, Characterization and Phylogenetic Analysis of Halophilic Archaea from a Salt Mine in Central Anatolia (Turkey)
}

\author{
EVRIM YILDIZ, BIRGUL OZCAN* AND MAHMUT CALISKAN
}

Mustafa Kemal University, Biology Department, 31040 Hatay-Turkey

Received 22 October 2011, revised 2 May 2012, accepted 5 May 2012

\begin{abstract}
The haloarchaeal diversity of a salt mine, a natural cave in central Anatolia, was investigated using convential microbiological and molecular biology methods. Eight halophilic archaeal isolates selected based on their colony morphology and whole cell protein profiles were taxonomically classified on the basis of their morphological, physiological, biochemical properties, polar lipid and protein profiles and $16 \mathrm{~S}$ rDNA sequences. From the $16 \mathrm{~S}$ rDNA sequences comparisons it was established that the isolates $\mathrm{CH} 2$, $\mathrm{CH} 3$ and $\mathrm{CHC}$ resembled Halorubrum saccharovorum by $98.8 \%, 98.9 \%$ and $99.5 \%$, respectively. There was a $99.7 \%$ similarity between the isolate CH11 and Halobacterium noricense and $99.2 \%$ between the isolate $\mathrm{CHA} 1$ and Haloarcula argentinensis. The isolate $\mathrm{CH} 8 \mathrm{~K}$ and $\mathrm{CH} 8 \mathrm{~B}$ revealed a similarity rate of $99.8 \%$ and $99.3 \%$ to Halococcus dombrowskii, respectively. It was concluded that the isolates named $\mathrm{CH} 2, \mathrm{CH} 3$ and $\mathrm{CHC}$ were clustered in the genus Halorubrum and that $\mathrm{CHA} 1$ and $\mathrm{CH} 7$ in the genus Haloarcula, $\mathrm{CH} 8 \mathrm{~K}$ and $\mathrm{CH} 8 \mathrm{~B}$ in the genus Halococcus and $\mathrm{CH} 11$ in the genus Halobacterium.
\end{abstract}

Ke y words: Halophilic archaea, Phylogeny, Taxonomy, Salt mine, Turkey

\section{Introduction}

The increasing interest, in recent years, in microorganisms from hypersaline environments has resulted in the discovery of several new species and genera belonging to the Bacteria and Archaea domains. Halobacteria are a group of microorganisms forming a part of the domain Archaea that require high salt concentration for growth (Kamekura, 1998). The extremely halophilic archaea belong to the order Halobacteriales, which contains one family, the Halobacteriaceae (Ozcan et al., 2007). The family Halobacteriaceae in the domain Archaea presently is comprised of 35 genera (Euzeby, 2011).

Members of the Halobacteriaceae are dominant microorganisms in hypersaline environments worldwide including salt lakes, crystallizer ponds of solar salterns, salt mines, as well as hypersaline soda lakes (Oren, 2000). The haloarchaea are well adapted to hypersaline environments and require at least $1.5 \mathrm{M}$ $\mathrm{NaCl}$ for growth (Castillo et al., 2007).

Hypersaline environments are commonly present in Turkey. Several studies have been carried out to isolate and characterize halophilic archaeal strains from various saline parts of Turkey (Elevi et al., 2004; Ozcan et al.
2006; 2009; Birbir et al., 2007). Phylogenetic studies revealed that the halophilic archaeal isolates from Turkey clustered closely to genera Halorubrum, Haloarcula, Natrinema, Halobacterium and Natronococcus (Ozcan et al., 2007; Birbir et al., 2007). However, there has been little effort to identify these isolates. Current taxonomic classification of the Halobacteriaceae is mainly based on DNA-DNA hybridization, 16S rRNA gene sequence comparison, polar lipid composition and phenotypic characteristics (Oren et al., 1997; Castillo et al., 2006).

The main purpose of the current research was to determine the halophilic archaeal diversity of a salt mine, formerly a natural cave in central Anatolia, by determining their phenotypic characteristics, polar lipid composition and 16S rRNA gene sequence comparison.

\section{Experimental}

Material and Methods

Physico-chemical analysis of the brine samples. Physico-chemical properties of the brine samples taken from the salt mine (Çankaya Salt Mine, Çankır1Turkey) were determined with Merc Spectroquant test

* Corresponding author: B. Ozcan, Mustafa Kemal University, Biology Department, 31040 Hatay-Turkey; phone: + 903262455336/1632; e-mail: birgulozcan@gmail.com 
kits and ICP-AES instrument. Test kits and Nova 60 spectrophotometer were used to detect the concentration of $\mathrm{SO}_{4}{ }^{2-}, \mathrm{Cl}^{-}, \mathrm{Ca}^{2+}, \mathrm{Mg}^{2+}, \mathrm{HCO}^{-}, \mathrm{CO}_{3}^{-2}, \mathrm{Na}^{+}, \mathrm{K}^{+}$and total hardness while a $\mathrm{pH}$ meter with glass electrode (WTW inoLab $\mathrm{pH} 720$ brand) was employed for $\mathrm{pH}$ measurement.

Isolation of extremely halophilic archaea. In order to isolate halophilic archaea, brine samples were collected in sterile bottles from different points in the salt mine. Each of the samples was inoculated in SG broth containing penicillin G. Aerobic enrichment cultures showing turbidity were streaked out onto solid medium containing penicillin G. Plates were incubated at $37.5^{\circ} \mathrm{C}$. After two weeks incubation period, representative colonies were transferred to fresh solid SG medium in order to obtain pure culture. SG medium contained (gl-1): $\mathrm{NaCl}, 250 ; \mathrm{MgSO}_{4} \cdot 7 \mathrm{H}_{2} \mathrm{O}, 20 ; \mathrm{KCl}, 2$; sodium citrate, 3 ; casamino acids, 7.5 ; yeast extract, 1 ; and $\mathrm{FeSO}_{4} \cdot 7 \mathrm{H}_{2} \mathrm{O}, 0.0023$. The $\mathrm{pH}$ was adjusted to 7.35 with $1 \mathrm{M} \mathrm{KOH}$ (Ozcan et al., 2006).

Phenotypic and cultural properties. Phenotypic tests of isolates were performed according to the proposed minimal standards for the description of new taxa in the order Halobacteriales (Oren et al., 1997). Cell motility and morphology were examined by phasecontrast microscopy of exponentially growing liquid cultures. Gram staining was carried out as described by Dussault (1955). Colony morphology was observed on optimal growth agar medium after incubation at $37.5^{\circ} \mathrm{C}$ for 7 days. Tests for catalase and oxidase activity and hydrolysis of starch, casein, gelatin and of esterase (Tween 20, 40, 60 and 80) were performed as explained before (Ozcan et al., 2006). Lipolytic activity was tested on Rhodamine agar plates (Ozcan et al., 2009). Nitrate reduction, $\mathrm{H}_{2} \mathrm{~S}$ formation, indole formation, utilization of sugars (Glucose, sucrose, lactose, fructose, maltose, xylose, mannose and ribose) and anaerobic growth in the presence of L-arginine and TMAO were tested according to Oren et al. (1997). Anaerobic growth in the presence of nitrate was tested according to Mancinelli and Hochstein (1986). The salt range for growth was determined in SG broth modified with $\mathrm{NaCl}$ at final concentrations of $1,2,3,4,4.5$ and $5 \mathrm{M}$. The $\mathrm{pH}$ range for growth was determined with $50 \mathrm{mM}$ MES (5.0-6.0), HEPES (6.5-7.0), tricine (7.5-8.5), CHES (9.0-9.5) and CAPS (10.0) between pH 5.0 and 10.0. Archaeal growth rates in different $\mathrm{pH}$ and salt concentrations were determined at $600 \mathrm{~nm}$ with spectrophotometric measurements.

Biochemical tests. Antibiotic susceptibility was tested by spreading cell suspensions on plates of SG medium and applying antibiotic discs (ampicillin, $10 \mu \mathrm{g}$; norfloxacin, $10 \mu \mathrm{g}$; tetracycline, $30 \mu \mathrm{g}$; bacitracin, 10IU; rifampicin, $5 \mu \mathrm{g}$; azithromycine, $15 \mu \mathrm{g}$; neomycin, $30 \mu \mathrm{g}$; chloramphenicol, $30 \mu \mathrm{g}$; penicillin G; 10IU; vancomycin, $30 \mu \mathrm{g}$; novobiocin, $30 \mu \mathrm{g}$; trimethoprim, $5 \mu \mathrm{g}$; ttreptomycin, $25 \mu \mathrm{g}$; erythromycin $15 \mu \mathrm{g}$; sulphamethazol/trimethoprim, $25 \mu \mathrm{g}$ ) (Montalvo-Rodriguez et al., 2000). The results were recorded as sensitive or resistant after 14 days of incubation at $37.5^{\circ} \mathrm{C}$. Polar lipid analysis was performed as explained before (Oren et al., 1996; Oren and Litchfield, 1999). SDS-PAGE of whole-cell proteins was set up as described by Laemmli (1970) and Hesselberg and Vreeland (1995).

Phylogenetic analysis. Genomic DNA was extracted from log-phase cells lysed in purified water by phenol extraction followed by ethanol precipitation according to Dyall-Smith (2001). The gene encoding 16S RNA was amplified by PCR with the forward primer 5'ATTCCGGTTGATCCTGCCGGAGGTC-3' (positions 1-25 according to Halobacterium cutirubrum NCIMB 763, GenBank Accession No. AB073366) and the reverse primer 5'-GATCCAGCCGCAGATTCCCC-3' (positions 1465-1446 according to Halobacterium cutirubrum NCIMB 763, GenBank Accession No. AB073366) (Ozcan et al., 2007). PCR was performed for 30 cycles, each of which consisted of denaturation for $1 \mathrm{~min}$ at $94^{\circ} \mathrm{C}$, annealing for $1 \mathrm{~min}$ at $59^{\circ} \mathrm{C}$, and polymerization for $1.5 \mathrm{~min}$ at $72^{\circ} \mathrm{C}$. The $16 \mathrm{~S}$ rRNA gene sequences were aligned using CLUSTAL W (Thompson et al., 1994) and the phylogenetic tree were constructed with MEGA 4.1 using a neighbor joining algorithm and Kimura twoparameter corrections (Tamura et al., 2007).

\section{Results and Discussion}

Physico-chemical properties of brine samples. The brine samples named CSU1, CSU2A, CSU2B and CSU3 were collected from four different points in the salt mine. Table I gives the chemical parameters of these samples in which halophilic archaea strains were isolated. The results indicated that the mineral content, $\mathrm{pH}$ and hardness of brine are suitable for the growth of extremely halophilic archaea. The most remarkable nature of halophilic archaea is that they flourish in conditions with very high content of $\mathrm{NaCl}$ and $\mathrm{KCl}$. Several researchers have determined that extreme halophilic archaea need at least $1.5 \mathrm{M} \mathrm{NaCl}$ for growth. They also point out that most species show optimum growth at 3.5 to $4.5 \mathrm{M} \mathrm{NaCl}$ and $\mathrm{pH} 7.0$ to 7.5 (Kushner, 1985; Arahal et al., 1996; Oren and R.-Valera, 2001).

Extremely halophilic archaeal strains and their phenotypic properties. It was pointed out that members of Halobacteriaceae family displayed extreme polymorphism, having several morphologic shapes ranging from rods to pleomorphic rods, coccus, pleomorphic, square and triangles (Castillo et al., 2007). In the current study 8 halophilic archaeal isolates named $\mathrm{CH} 2$, $\mathrm{CH} 3, \mathrm{CHA} 1, \mathrm{CHC}, \mathrm{CH} 7, \mathrm{CH} 8 \mathrm{~K}, \mathrm{CH} 8 \mathrm{~B}$ and $\mathrm{CH} 11$, 
Table I

Chemical characteristics of the brine samples studied

\begin{tabular}{|l|c|c|c|c|c|}
\hline & Csu1 & Csu2A & Csu2B & Csu3 & Pw $^{*}$ \\
\hline $\mathrm{pH}$ & 6.61 & 7.03 & 7.06 & 6.72 & 6.0 \\
\hline Hardness (F) & 3.8 & 3.1 & 3.8 & 3.7 & $<1.2$ \\
\hline $\mathrm{SO}_{4}^{-2}(\mathrm{mg} / \mathrm{L})$ & 7400 & 7400 & 7500 & 7500 & 8 \\
\hline $\mathrm{Cl}^{-}(\mathrm{mg} / \mathrm{L})$ & 209000 & 230000 & 192000 & 200000 & $<10$ \\
\hline $\mathrm{CO}_{3}^{-2}(\mathrm{meq} / \mathrm{L})$ & - & - & - & - & - \\
\hline $\mathrm{HCO}_{3}^{-}(\mathrm{meq} / \mathrm{L})$ & 1.2 & 1.6 & 2.2 & 1.8 & - \\
\hline $\mathrm{Ca}^{2+}(\mathrm{ppm})$ & 790 & 920 & 970 & 940 & - \\
\hline $\mathrm{Mg}^{2+}(\mathrm{ppm})$ & 530 & 490 & 510 & 560 & - \\
\hline $\mathrm{K}^{+}(\mathrm{ppm})$ & 210 & 190 & 190 & 240 & - \\
\hline $\mathrm{Na}^{+}(\mathrm{ppm})$ & 67200 & 18600 & 102300 & 88700 & - \\
\hline
\end{tabular}

* Purified water

were selected on the basis of their different colony morphology and whole cell profiles for further characterization. Table II shows the morphological features of the isolates, results of several biochemical tests, antimicrobial susceptibility patterns, and $\mathrm{NaCl}$ and $\mathrm{pH}$ concentrations required for optimum growth. When whole cell protein profiles were examined (Fig. 1), seven distinct protein profiles were observed for eight different strains. $\mathrm{CH} 8 \mathrm{~K}$ and $\mathrm{CH} 8 \mathrm{~B}$ isolates were ascertained to have the same protein profile but due to their different colony pigmentations they were named differently.

$\mathrm{CH} 2, \mathrm{CH} 3$ and $\mathrm{CHC}$ isolates exhibited different protein profile (Fig. 1) and among the phenotypical features obtained, only colony pigmentation and sugar fermentation were different. $\mathrm{CH} 2$ and $\mathrm{CHC}$ isolate can produce acid from sucrose and mannose while $\mathrm{CH} 3$ cannot. $\mathrm{CH} 2$ can ferment maltose while $\mathrm{CH} 3$ and $\mathrm{CHC}$ isolate cannot. One of the notable features is that

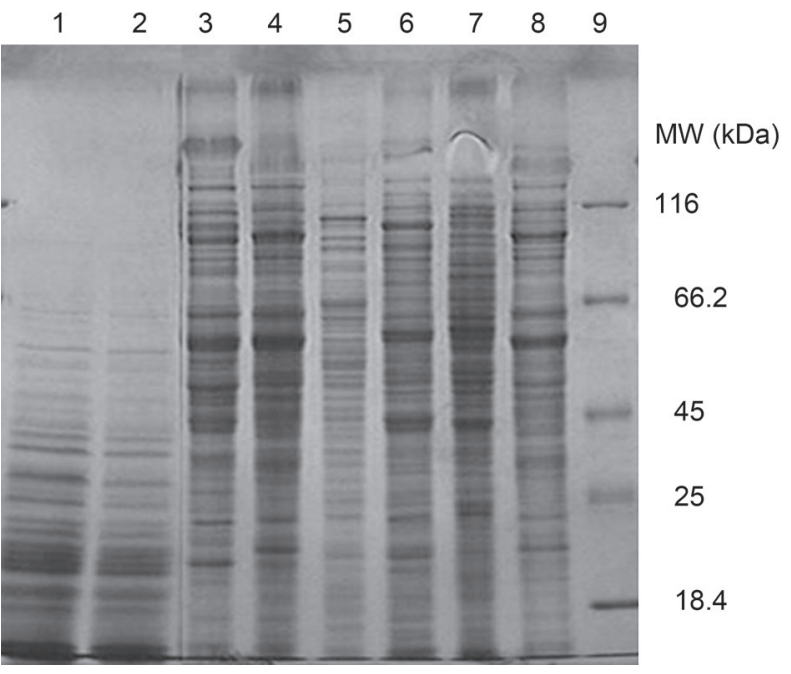

Fig. 1. Protein profiles of the archaeal strains isolated from Cankırı Cankaya Salt mine.

1: CH8K, 2: CH8B, 3: $\mathrm{CH} 3$, 4: CHC, 5: CH11, 6: CH7, 7: CHA1, 8: $\mathrm{CH} 2$, 9: Markers
$\mathrm{CH} 2, \mathrm{CH} 3$ and $\mathrm{CHC}$ isolates are resistant to the antibiotic rifampicin. Several studies point out that rifampicin has an inhibiting effect on most halophilic archaea (Pecher and Böck, 1981; Bonelo et al., 1984) whereas another research points out that certain halophilic archaea are resistant to rifampicin (Allen et al., 2008). All isolates in this study appeared to be resistant to ampicillin, norfloxacin, tetracycline, azithromycine, neomycin, chloramphenicol, penicillin G, vancomycin, trimethoprim, streptomycin, erythromycin and sulphamethazol/ trimethoprim.

$\mathrm{CH} 8 \mathrm{~B}$ and $\mathrm{CH} 8 \mathrm{~K}$ which are coccus-shaped, non motile isolates were determined to be Gram-variable while other isolates were Gram-negative. Three of six motile Gram-negative isolates were of pleomorphic shapes while the other three rod shaped. It was reported that majority of Halobacteriales order were of Gramnegative nature while some other members with coccus morphology such as Natronococcus and Halococcus exhibited Gram-variable feature (Oren et al., 1997).

It was observed that colonies of all eight strains are nonmucoid, circular shaped and convex. They have smooth surface appearance and that all strains but $\mathrm{CH} 8 \mathrm{~B}$ exhibited pink-red colony pigmentation. It was pointed out in several former studies that colonies of many Halobacterial members exhibited various tones pigmentation ranging from red to pink-orange due to high rate of carotenoid pigments in their cell membrane. In addition, they were reported to appear opaque, transparent or translucent, mucoid or non mucoid, with entire edges and convex (Oren and R.-Valera, 2001; Castillo et al., 2006).

It was ascertained that all strains but $\mathrm{CH} 11$ exhibited catalase activity and that all the isolates had oxidase activity. It was also determined that none of the isolates produced gas from the tested sugars or acid from lactose. It was established that none of the isolates exhibited lipolytic activity (Table II). 
Table II

Phenotypic features of the 8 strains studied

\begin{tabular}{|c|c|c|c|c|c|c|c|c|}
\hline Characteristic & $\mathrm{CH} 2$ & $\mathrm{CH} 3$ & CHA1 & $\mathrm{CHC}$ & $\mathrm{CH} 7$ & CH8K & $\mathrm{CH} 8 \mathrm{~B}$ & CH11 \\
\hline \multicolumn{9}{|l|}{ Colonial morphology } \\
\hline Colony shape & circular & circular & circular & circular & circular & circular & circular & circular \\
\hline Mukoid & - & - & - & - & - & - & - & - \\
\hline Pigmentation & light pink & light red & dark red & light red & red & pink-red & white & red \\
\hline Colony elevation & convex & convex & convex & convex & convex & convex & convex & convex \\
\hline Colony density & transparent & translucent & opaque & transparent & opaque & opaque & opaque & transparent \\
\hline Colony edge & entire & entire & entire & entire & entire & irregular & irregular & entire \\
\hline Colony size $(\mathrm{mm})$ & $0.3-0.75$ & $0.25-0.6$ & $0.2-0.5$ & $0.4-0.7$ & $0.2-0.5$ & $0.1-0.2$ & $0.1-0.2$ & $0.15-0.25$ \\
\hline \multicolumn{9}{|l|}{ Cell morphology } \\
\hline Cell shape & rod & rod & pleo. & rod & pleo. $^{1}$ & coccus & coccus & pleo. ${ }^{1}$ \\
\hline Gram reaction & $\operatorname{Gr}(-)$ & $\operatorname{Gr}(-)$ & $\operatorname{Gr}(-)$ & $\operatorname{Gr}(-)$ & $\operatorname{Gr}(-)$ & $\mathrm{Gr}(+/-)$ & $\operatorname{Gr}(+/-)$ & $\operatorname{Gr}(-)$ \\
\hline Motility & + & + & + & + & + & - & - & + \\
\hline Cell size $(\mu \mathrm{m})$ & $2-15$ & $2-10$ & ND & $2-10$ & ND & $1-3$ & $1-3$ & $1-3$ \\
\hline \multicolumn{9}{|l|}{ Acid production from } \\
\hline Glucose & + & + & - & + & - & - & - & + \\
\hline Sucrose & + & - & - & + & - & - & - & - \\
\hline Lactose & - & - & - & - & - & - & - & - \\
\hline Fructose & - & - & + & - & + & - & - & - \\
\hline Maltose & + & - & + & - & + & - & - & - \\
\hline Xylose & + & + & + & + & + & - & - & + \\
\hline Mannose & + & - & - & + & - & - & - & - \\
\hline Ribose & - & - & + & - & + & + & + & + \\
\hline \multicolumn{9}{|l|}{ Anaerobic growth with } \\
\hline L-Arginine & - & - & - & - & - & - & - & - \\
\hline TMAO & - & - & - & - & - & - & - & - \\
\hline $\mathrm{KNO}_{3}$ & - & - & - & - & + & - & - & - \\
\hline Catalase activity & + & + & + & + & + & + & + & - \\
\hline Oxidase activity & + & + & + & + & + & + & + & + \\
\hline Gelatin hydrolysis & - & - & + & - & - & + & + & - \\
\hline Casein hydrolysis & - & - & - & - & - & + & + & - \\
\hline Starch hydrolysis & - & - & + & - & - & - & - & - \\
\hline Lipolytic activity & - & - & - & - & - & - & - & - \\
\hline Tween 20 hydrolysis & - & - & + & - & + & + & + & + \\
\hline Tween 40 hydrolysis & - & - & + & - & + & - & - & + \\
\hline Tween 60 hydrolysis & - & - & + & - & - & - & - & - \\
\hline Tween 80 hydrolysis & - & - & + & - & - & - & - & - \\
\hline $\mathrm{H}_{2} \mathrm{~S}$ production & + & + & - & + & + & + & + & - \\
\hline Indole production & - & - & + & - & - & + & + & - \\
\hline Nitrite from nitrate & + & + & + & + & + & + & + & - \\
\hline Gas from nitrate reduction & - & - & + & - & + & - & - & - \\
\hline Optimum $\mathrm{NaCl}(\mathrm{M})$ & 4.5 & 3.5 & 4.5 & 3.5 & 4.5 & 4.5 & 4.5 & 3.5 \\
\hline Optimum pH & 7 & 7.5 & 7 & 7.5 & 7 & 7 & 7 & 7 \\
\hline \multicolumn{9}{|l|}{ Sensitivity to } \\
\hline Novobiocin $(30 \mu \mathrm{g})$ & $\mathrm{S}^{2}$ & $S$ & $S$ & $S$ & $\mathrm{~S}$ & $S$ & $S$ & $\mathrm{~S}$ \\
\hline Bacitracin (10 IU) & $S$ & S & S & S & $S$ & $\mathrm{~S}$ & S & $S$ \\
\hline Rifampicin $(5 \mu \mathrm{g})$ & $\mathrm{R}^{3}$ & $\mathrm{R}$ & $S$ & $\mathrm{R}$ & $S$ & $S$ & $S$ & $S$ \\
\hline
\end{tabular}

${ }^{1}$ pleomorphic, ${ }^{2}$ sensitive, ${ }^{3}$ resistant 
No anaerobic growth was observed in any strain in the presence of L-arginine and TMAO whereas it yielded a positive result only with $\mathrm{CH} 7$ strain in the presence of $\mathrm{KNO}_{3}$. Most halophilic Archaea have the ability to grow anaerobically in the presence of different chemicals due to their relatively low oxygen solubility under high salinity conditions. They were reported (Hartmann et al., 1980; Mancinelli and Hochstein, 1986; Oren and Trüper; 1990; Oren and Litchfield, 1999) to have the ability to use alternative electron acceptors such as fumarate, TMAO and/or nitrate in order to perform anaerobic growth.

Polar lipid chromatograms of standard strains and the isolates from the Cankaya Salt Mine are given in Fig. 2. According to the chromatographic results, all isolates were found to contain PG and PGP-Me phospholipids. It was observed that all strains but $\mathrm{CH} 8 \mathrm{~K}$ and CH8B isolates contain PGS.

Phylogenetic analysis. Phylogenetic analysis of the extremely halophilic archaeal isolates were performed by building a phylogenetic tree which was constructed based on the 16S rRNA gene sequences (Fig. 3). When $16 \mathrm{~S}$ rRNA sequential analyses are taken into consideration, CH11 strain was determined to resemble Halobacterium noricense by $99.7 \%$ ratio. $\mathrm{CH} 11$ isolate is a strain with a pleomorphic cellular shape, which can utilize glucose and xylose. CH11 is susceptible to bacitracin antibiotics and cannot grow anaerobically.

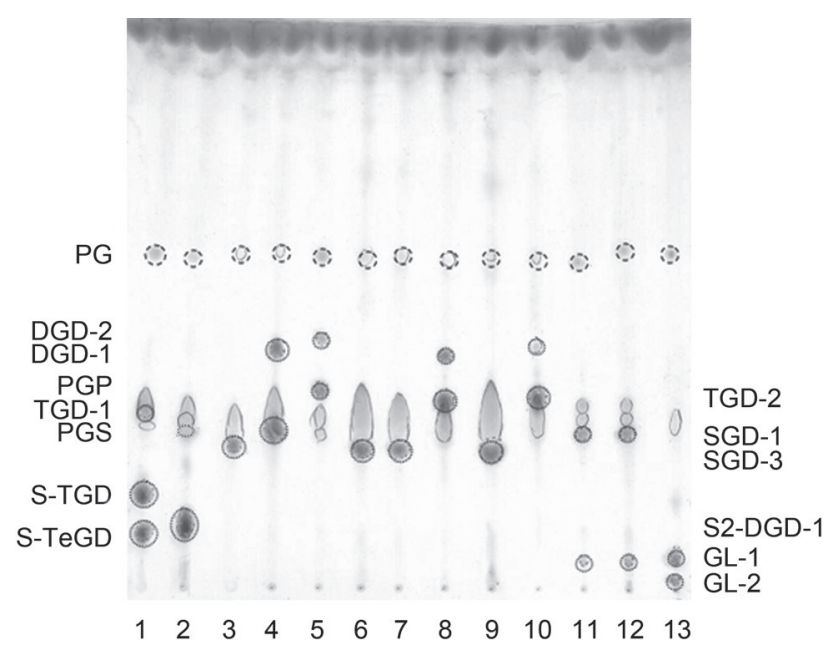

Fig. 2. Results of thin layer chromatography analysis of polar lipids extracted from halophilic archaeal isolates from the Cankaya Salt Mine

1: Halobacterium salinarum (DSM 3754); 2: Natrialba asiatica (DSM 12278); 3: Halorubrum saccharovorum (DSM 1137); 4: Haloferax denitrificans (DSM 4425); 5: Haloarcula vallismortis (DSM 3756); 6: CH2; 7: CH3; 8: CHA1; 9: CHC; 10: CH7; 11: CH8K; 12: CH8B; 13: CH11. (PG, phosphatidylglycerol; PGP, phosphatidylglycerolphosphate; PGS, phosphatidylglycerolsulfate; S-DGD-3, sulfated glycosyl diether (mannose $(1 \rightarrow 4)$-glucoseglyceroldiether); S-DGD-1, sulfated glycosyl diether (mannose $(1 \rightarrow 2)$-glucose glycerol diether); S2-DGD-1, bis-sulfated diglycosyl diether; S-TGD, sulfated triglycosyl diether; S-TeGD, sulfated tetraglycosyl diether; DGD-2, diglycosyl diether; DGD-1, diglycosyl diether (mannose $(1 \rightarrow 2)$ glucose glycerol diether); TGD-1, triglycosyl diether; (galactosylmannosyl-glucosyl diether); TGD-2, triglycosyl diether GL, undefined glycolipid)

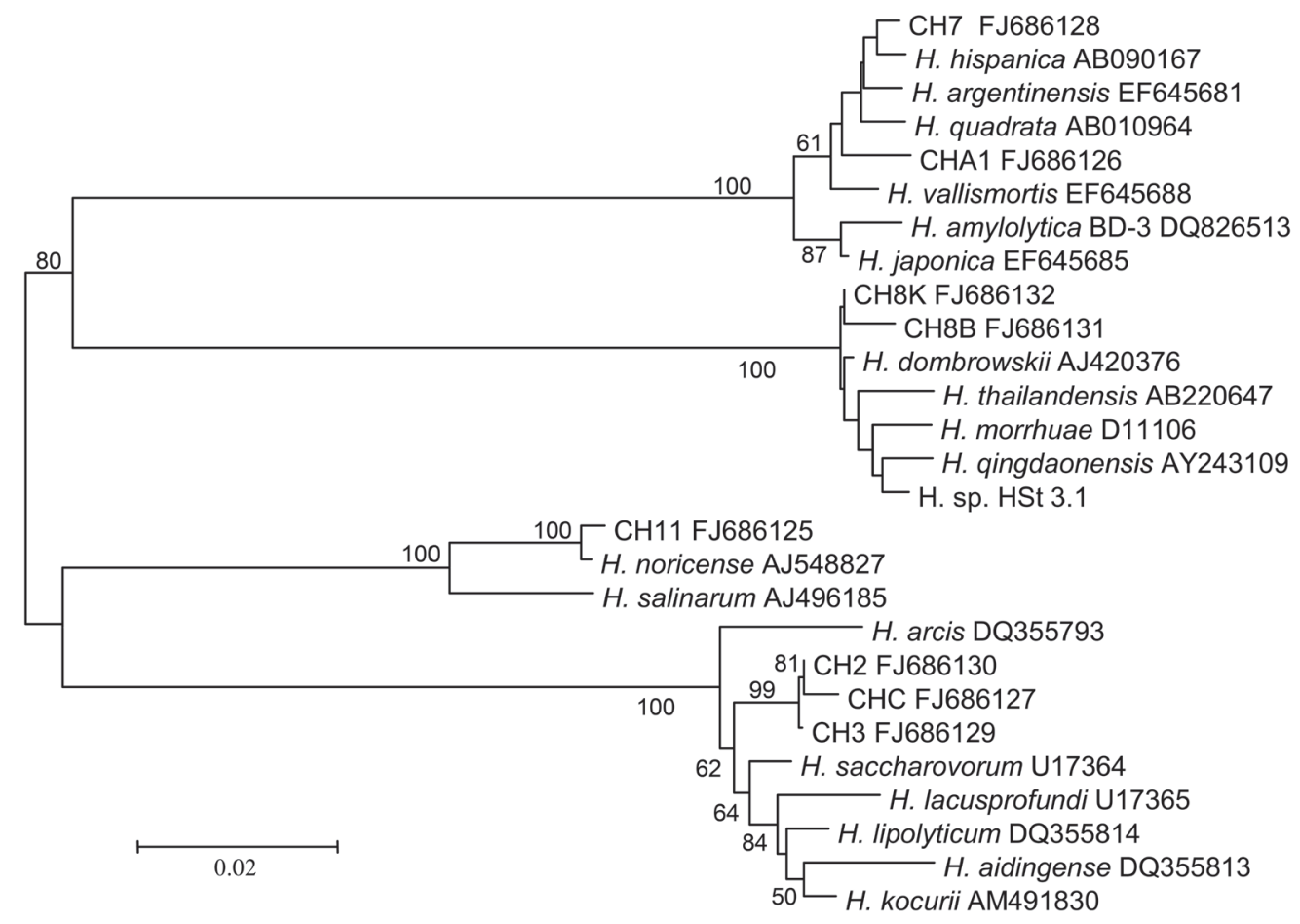

Fig. 3. Phylogenetic tree showing the relationships among the $16 \mathrm{~S}$ rRNA gene sequences of Cankaya salt mine isolates and the closest relatives within the family Halobacteriaceae

Bootstrap values, expressed as percentages of 1000 replicates, are shown for branches with more than $50 \%$ bootstrap support. Bar, 0.02 substitutions per site 
As for H. noricense, it has the form of rod cells, cannot make use of glucose or xylose sugars and are resistant to bacitracin and exhibits anaerobic growth in the presence of L-Arginine (Gruber et al., 2004). While isolate $\mathrm{CH} 11$ was found to contain two undefined glycolipids in addition to PGS, PG and me-PGP lipids, it is reported that $H$. noricense contained PG, me-PGP, PGS, TGD and S-TeGD lipids (Gruber et al., 2004). Taking into consideration different phenotypical and chemical features between these two strains, it is suggested that isolate $\mathrm{CH} 11$ might be a separate species within genus Halobacterium.

The resemblance of $\mathrm{CH} 8 \mathrm{~K}$ and $\mathrm{CH} 8 \mathrm{~B}$ isolates to the species Halococcus dombrowskii is by $99.8 \%$ and $99.3 \%$, respectively. It was revealed that $\mathrm{CH} 8 \mathrm{~K}$ and $\mathrm{CH} 8 \mathrm{~B}$ strains (the current study) and Halococcus dombrowskii species (Stan-Lotter et al., 2002) shared the properties of being coccus-shaped nonmotile cells, positive catalase, oxydase, gelatinase activities and nitrate reduction as well as containing lipids PG, PGP-me and S-DGD1 but PGS. On the other hand, it was established that $\mathrm{CH} 8 \mathrm{~K}$ and $\mathrm{CH} 8 \mathrm{~B}$ isolates, which were Gram-variable and have colony pigmentations pink-red and white respectively, could not ferment xylose or fructose sugars and contained one undefined glycolipid in addition to PG, me-PGP and S-DGD1. Meanwhile, the species Halococcus dombrowskii was reported to be Gramnegative, and to exhibit light red pigmentation and to be able to use fructose and xylose (Stan-Lotter et al., 2002). Except for colony pigmentation all other features of $\mathrm{CH} 8 \mathrm{~K}$ and $\mathrm{CH} 8 \mathrm{~B}$ isolates were found to be the same. It was reported that the number of insertion sequences in the chromosomes of halophilic archaea was rather high, and this caused a high frequency of spontaneous mutations (DasSarma, 1993). Such a mutation might be the cause of the difference in pigmentation of isolates $\mathrm{CH} 8 \mathrm{~K}$ and $\mathrm{CH} 8 \mathrm{~B}$.

It was established that strain CHA1 resembled Haloarcula argentinensis by the ratio of $99.2 \%$. CHA1 and H. argentinensis (Ihara et al., 1997) have Gram-negative and motile cells and they exhibit oxydase and catalase activities and can produce acid from fructose, maltose and ribose. Moreover, they have TGD-2 as essential glycolipid. However, unlike H.argentinensis, strain CHAl cannot produce acid from glucose, sucrose and mannose. CHA1 strain differs from $H$. argentinensis by having pleomorphic cell shape and DGD-1 in addition to glycolipid TGD-2.

$\mathrm{CH} 2, \mathrm{CH} 3$ and $\mathrm{CHC}$ strains were clustered with Halorubrum genus and their similarity to Halorubrum saccharovorum species was found to be $98.8 \%, 98.9 \%$ and $98.5 \%$, respectively. Isolates $\mathrm{CH} 2, \mathrm{CH} 3$ and $\mathrm{CHC}$ and $H$. saccharovorum share the properties of being rod shaped motile cells, stained Gram-negative, strict aerobic growth, positive oxidase and catalase activity and nitrate reduction (McGenity and Grant, 1996). They are also alike by having S-DGD-3 glycolipid in addition to essential phospholipids.

Isolate $\mathrm{CH} 7$ was determined to resemble Haloarcula hispanica species to the rate of $99.5 \%$. When phenotypical characteristics of $\mathrm{CH} 7$ isolate and $\mathrm{H}$. hispanica (Juez et al., 1986) species were compared, both strains were found to have pleomorphic motile Gram-negative cells, and positive nitrate reduction and nitrate gas formation and that they could grow anaerobically in presence of nitrate. Moreover, both strains were found to contain TGD-2 glycolipid. On the other hand, isolate $\mathrm{CH} 7 \mathrm{did}$ not exhibit gelatinase, caseinase and amylase activity, whereas species $H$. hispanica is positive in gelatinase, caseinase and amylase activity.

As a result, in the current study we have isolated and characterized 8 different isolates from a salt mine located in central Anatolia. The characterization of the isolates was carried out using a polyphasic approach. According to $16 \mathrm{~S}$ rRNA sequential analysis, which is one of the most determining molecular taxonomic methods, these eight isolates were found to cluster in four different genera which are Halobacterium, Halococcus, Haloarcula and Halorubrum. The results presented herein may contribute to archaeal taxonomy, particularly to halophilic archaeal species habituating saltern cave environments.

\section{Acknowledgements}

Financial support from TUBITAK (Turkish Science and Technological Research Counsel)-Turkey and Research Council of Mustafa Kemal University-Turkey is gratefully acknowledged.

\section{Literature}

Allen A.M., F. Goh; S. Leuko, A. Echigo, T. Mizuki, R. Usami, M. Kamekura, B.A. Neilan and P. Burns. 2008. Haloferax elongans sp. Nov. And Haloferax mucosum sp. Nov., isolated from microbial mats from Hamelin Pool, Shark Bay, Australia. Int. J. Syst. Evol. Microbiol. 58: 798-802.

Arahal D.R., F.E. Dewhirst, B.J. Paster, B.E Volcani and A. Ventosa. 1996. Phylogenetic analyses of some extremely halophilic archaea isolated from dead sea water, determined on the basis of their 16 S rRNA sequences. Appl. Environ. Microb. 62: 3779-3786. Birbir M., B. Calli, B. Mertoglu, E.R. Bardavid, A. Oren, M.N. Ogmen and A. Ogan. 2007. Extremely halophilic archaea from Tuz Lake, Turkey, and the adjacent Kaldirim and Kayacik salterns. World J. Microbiol. Biotechnol. 23: 309-316.

Bonelo G., A. Ventosa, M. Megias and F. Ruiz-Berraquero. 1984. The sensitivity of halobacteria to antibiotics. FEMS Microbiol. Lett. 21: 341-345.

Castillo A.M., M.C. Gutierrez, M. Kamekura, Y. Ma, D.A Cowan, B.E. Jones, W.D. Grant and A. Ventosa. 2006. Halovivax asiaticus gen. Nov., sp. Nov., a novel extremely halophilic archaeon isolated from inner Mongolia, China. Int. J. Syst. Evol. Microbiol. 56: 765-770. Castillo A.M., M.C. Gutierrez, M. Kamekura, Y. Xue, Y. Ma, D.A Cowan, B.E. Jones, W.D. Grant and A. Ventosa. 2007. Haloru- 
brum ejinorense sp. Nov., isolated from lake Ejinor, inner Mongolia, China. Int. J. Syst. Evol. Microbiol. 57: 2538-2542.

DasSarma S. 1993. Identification and analysis of the gas vesicle gene cluster on an unstable plasmid of Halobacterium halobium. Experientia 49: 482-486.

Dussault H.P. 1955. Am improved technique for staining red halophilic bacteria. J. Bacteriol. 70:484-485.

Dyall-Smith M. 2001. The halohandbook: protocols for halobacterial genetics (4.5 version electronic publication).

Elevi R., P. Assa, M. Birbir, A. Ogan and A. Oren. 2004. Characterization of extremely halophilic Achaea isolated from the Ayvalık Saltern, Turkey. World J. Microbiol. Biotechnol. 20: 719-725.

Euzéby J.P. 2011. List of prokaryotic names with standing in nomenclature. Available at: http://www.bacterio.cict.fr/classifgenerafamilies.html\#Halobacteriaceae. Accessed 09 September 2011.

Gruber C., A. Legat, M. Pfaffenhuemer, C. Radax, G. Weidler, H.C. Busse and H. Stan-Lotter. 2004. Halobacterium noricense sp. nov., an archaeal isolate from a bore core of an alpine Permian salt deposit, classification of Halobacterium sp. NRC-1 as a strain of H. salinarum and emended description of H. Salinarum. Extremophiles. 8: 431-439.

Hartmann R., H.D. Sickinger and D. Oesterhelt. 1980. Anaerobic growth of halobacteria. Proc. Natl. Acad. Sci. USA 77: 3821-3825.

Hesselberg M. and R.H. Vreeland. 1995. Utilization of protein profiles for the characterization of halophilic bacteria. Curr. Microbiol. 31: 158-162.

Ihara K., S. Watanabe and T. Tamura. 1997. Haloarcula argentinensis sp. nov. and Haloarcula mukohataei sp. nov., Two New Extremely Halophilic Archaea Collected in Argentina. Int. J. Syst. Bacteriol. 47: 73-77.

Juez G., F. Rodriguez-Valera, A. Ventosa and D.J. Kushner. 1986. Haloarcula hispanica spec. nov. and Haloferax gibbonsii spec. nov., two new species of extremely halophilic archaebacteria. Syst. Appl. Microbiol. 8: 75-79.

Kamekura M. 1998. Diversity of extremely halophilic bacteria. Extremophiles. 2: 289-295.

Kushner D.J. 1985. The Halobacteriaceae, pp. 171-214. In: Woese, C.R. and R.S. Wolfe (eds). The bacteria a treatise on structure and function Archaebacteria. Vol. III. New York, Academic Press.

Laemmli U.K. 1970. Cleavage of structural proteins during the assembly of the head of bacteriophage T4. Nature. 227: 680-685.

Mancinelli R.L. and L.I. Hochstein. 1986. The occurrence of denitrification in extremely halophilic bacteria. FEMS Microbiol. Lett. 35: 55-58.

McGenity T. and W.D. Grant. 1996. Transfer of Halobacterium saccharovorum, Halobacterium sodomonse, Halobacterium trapanicum NRC 34021 and Halobacterium lacusprofundi to the genus Halorubrum gen. nov., as Halorubrum saccharovorum comb. nov.,
Halorubrum sodomonse comb. nov., Halorubrum trapanicum comb. nov., and Halorubrum lacusprofundi comb. nov. Syst. Appl. Microbiol. 18: 237-243.

Montalvo-Rodriguez R., J. Lopez-Garriga, H. Vreeland, A. Oren, A. Ventosa and M. Kamekura. 2000. Haloterrigena thermotolerans sp. nov., a halophilic archaeon from Puerto Rico. Int. J. Syst. Evol. Microbiol. 50: 1065-1071.

Oren A. and H.G. Trüper. 1990. Anaerobic growth of halophilic archaeobacteria by reduction of dimethylsulfoxide and trimethylamine N-oxide. FEMS Microbiol. Lett. 70: 33-36.

Oren A., S. Duker and S. Ritter. 1996. The polar lipid composition of Walsby's square bacterium. FEMS Microbiol. Lett. 138: 135-140.

Oren A., A. Ventosa and W.D. Grant. 1997. Proposed minimal standarts for description of new taxa in the order Halobacteriales. Int. J. Syst. Bacteriol. 47: 233-238 .

Oren A. and D.C. Litchfield. 1999. A procedure for the enrichment and isolation of Halobacterium. FEMS Microbiol. Lett. 173: 353-358.

Oren A. 2000. Biological processes in the Dead sea as influenced by short-term and long-term salinity changes. Arch. Hydrobiol. Spec. Issues. Advanc. Limnol. 55: 531-542.

Oren A. and F. Rodriguez-Valera. 2001. The contribution of halophilic bacteria to coloration of saltern crystallizer ponds. FEMS Microbiol. Ecol. 36: 123-130.

Ozcan B., C. Cokmus, A. Coleri and M. Caliskan. 2006. Characterization of extremely halophilic archaea isolated from saline environment in different parts of Turkey. Microbiology. 75: 739-748. Ozcan B., G. Ozcengiz, A. Coleri and C. Cokmus. 2007. Diversity of halophilic archaea from six distinct parts of Turkey. J. Microbiol. Biotechnol. 17: 985-992.

Ozcan B., G. Ozyilmaz, C. Cokmus and M. Caliskan. 2009. Characterization of extracellular esterase and lipase activities from five halophilic archaeal strains. J. Ind. Microbiol. Biotechnol. 36: 105-110. Pecher T. and A. Böck. 1981. In vivo susceptibility of halophilic and mathanogenic organisms to protein synthesis inhibitors. FEMS Microbiol. Lett. 10: 295-297.

Stan-Lotter H., M. Pfaffenhuemer, A. Legat, H.J. Busse, C. Radax and C. Gruber. 2002. Halococcus dombrowskii sp. nov., an archaeral isolate from a permian alpine salt deposit. Int. J. Syst. Evol. Microbiol. 52: 1807-1814.

Tamura K., J. Dudley, M. Nei and S. Kumar. 2007. MEGA4: Molecular Evolutionary Genetics Analysis (MEGA) Software Version 4.0. Mol. Biol. Evol. 24(8): 1596-1599.

Thompson J.D., D.G. Higgins and T.J. Gibson. 1994. Clustal In: Improving the sensitivity of progressive multiple sequence alignment through sequence weighting positionspecific gap penalties and weight matrix choice. Nucleic Acids Res. 22: 4673-4680. 